\title{
Reproduction Health Based on Various Kinds of Women's Blood in Serat Piwulang Estri and Risalah Al-Mahîd: Philological and Comparative Studies
}

\author{
Siti Musarofah ${ }^{1 *}$, Ummi Mahmudah $^{1}$ \\ ${ }^{1}$ Institut Agama Islam Riyadlatul Mujahidin (IAIRM) \\ Kompleks Pondok Pesantren Walisongo, Ngabar, Ponorogo, East Java, 63471, INDONESIA \\ *Corresponding Author
}

DOI: https://doi.org/10.30880/jstard.2020.02.03.007

Received 30 September 2020; Accepted 30 November 2020; Available online 31 December 2020

\begin{abstract}
It is not only the cycle of menstruation that shows a woman's reproductive health, but also the color of menstrual blood. Studying ancient manuscripts can add insight. Serat Piwulang Estri and Risalah Al-Mahîd are two ancient manuscripts containing various color types of women's blood. But the problem is that both manuscripts are written in Javanese and not all women understand Javanese. This study aims to: find out the types of women's blood mentioned in Serat Piwulang Estri and Risalah Al-Mahîd, conduct philology studies by comparing the contents of these texts, and to analyze the relationship between types of women's blood and women's reproductive health. The library review method used in this study. The results are: In Serat Piwulang Estri it is mentioned four colors of strong blood and one color of weak blood. In Risalah Al-Mahîd, there are three colors of strong blood, two colors of weak blood and one characteristic of weak blood, which is thin. Pink blood is not mentioned in Serat Piwulang Estri but in Risalah Al-Mahîd. Yellow blood is considered strong blood in Serat Piwulang Estri but in Risalah Al-Mahîd it is considered weak blood.
\end{abstract}

Keywords: Reproduction health, Serat Piwulang Estri, Risalah Al-Mahîd, strong blood, weak blood

\section{Introduction}

Risalah Al-Mahîd important for women, especially Muslim women, because the book contains are various knowledge of women's blood, those are; menstrual blood, puerperal blood, and istihadah blood or blood of disease. Explained in this book how Muslim women who are experiencing menstruation and puerperal (after childbirth) are forbidden to do some worship such as prayer, fasting, reading the Qur'an, tawaf, prostration of gratitude, prohibited for entering the mosque, and also prohibited for having sex. Explained there the calculation of the menstrual time at least 24 hours continuously and at most 15 days, and the puerperal time count of at least one drop and at most 60 days [1].

Serat Piwulang Estri also important for women, because this text contains education for women, as is Risalah AlMahîd. This text explained the types of women's blood i.e. menstrual blood, puerperal blood and istihadah blood. Types of menstrual blood are strong blood and weak blood. Various colors of menstrual blood, explained also in Serat Piwulang Estri [2].

Reproductive health is a condition that is perfect physically, spiritually, and socially and frees from disease or disability from all aspects related to reproductive organs, reproductive functions, and reproductive processes [3]. One way to maintain reproductive health is to make an introduction to the reproductive system, processes, and functions of the reproductive organs. Female reproductive organs consist of ovary, fimbriae, tubafalupi, uterus, cervix, vagina, and labia [4].

Normally, a female reproductive organ every month excretes the blood, called menstrual blood. Judging from the type of color, odor, and thickness, menstrual blood varies, depending on the severity of the activities carried out by women every day. In addition to menstrual blood, women also excrete other types of blood from the reproductive organs, such as puerperal blood, and blood of istihadah or blood of disease. [1] 
Reproductive health is related to the mechanism of the reproductive system, namely the period of pregnancy and menstruation. Menstruation is experienced by healthy women. The menstruating women show that their reproductive organs are running according to their functions, and are a sign that women are entering the fertile period. Women who are menstruating mean that they are not pregnant. Some women still bleed even though menstruation is over, as well as some women continue to bleed even though the puerperal period is over. To be able to distinguish between menstrual blood, puerperal blood, and blood of disease, women need to understand the characteristics or signs of each blood. It's important to know all kinds of women's blood, considering all of that blood coming out of the female reproductive organs. [5].

Knowledge of various types of women's blood can be obtained through books, magazines, and the internet. In addition to that, there are also ancient manuscripts whose contents knowledge about various types of women's blood even the text was added with knowledge about courtesy that should be done by them when the female reproductive organs are bleeding. Ancient manuscripts in Indonesia are generally written in the environment of the palace or boarding schools. Including ancient manuscripts that discuss various types of women's blood are Serat Piwulang Estri and Risalah Al-Mahîd. Both Serat Piwulang Estri and Risalah Al-Mahîd are important to learn by the women because there are instructions in those manuscripts for women in efforts to maintain the health of their reproductive organs.There are several similarities and differences between the types of female blood in the text of Serat Piwulang Estri and Risalah Al-Mahîd that are important for women to know. But the problem is, both texts are written in ancient Javanese, and not all women can understand Javanese. For this reason, we will try to compare those two texts in the study of philology.

According to [6] study of ancient manuscripts can reopen knowledge in the past. Thus the old literature can be used as material to reconstruct the fabric of society, patterns of social relations, values that support the society in which the ancient manuscripts were born, and the situations that took place at that time.

We will compare the types of women's blood mentioned in Serat Piwulang Estri and Risalah Al-Mahîd in this article. Then we will discuss the types of blood color with reproductive health because the blood coming out of the women reproductive organs (vagina) has a relationship with reproductive health.

\section{Literature Review}

Research on content of Risalah Al-Mahîd and content of Serat Piwulang Estri has been conducted by several previous researchers. But they do not compare the contents of these two texts.

Masfiah's research on Risalah Al-Mahîd explained the bloods of women are; menstruation blood, puerperal blood, and istihadah blood. Those bloods are including part of the discussion of fiqih, chapter thaharah and chapter women's blood. She explained; first, about menstruation (the age of the woman experiencing her first menstruation is 9 years or 9 years less than 16 days), she also explined about time of menstrual bleeding, menstrual blood color, things that are prohibited and required for menstruating women. Second, puerperal (time of puerperal bleeding, puerperal blood color, things that are prohibited and required for puerperal women). Third istihadah, time of istihadah bleeding, istihadah blood color, and things prohibited and required from a woman who's in istihadah conditions. Masfiah focused her research on obligations for Muslim women who are in the first day of menstruation had not yet done prayer, even though it was already entered prayer time, than she was obliged to substitute her prayer later after the menstruation was over [7].

Wulandari's research explained the contents of the Serat Piwulang Estri are manifestation of Javanese women in three parables. First, agricultural land, the meaning is likened women to agricultural land to prepare the next generation. Second, tools of weaving, the meaning is likened women to looms to educate the next generation. And third, batik land, the meaning is likened women to a place to do the coloring process of the next generation [8].

Ismawarsari and Ningrum in their research about Serat Piwulang Estri finding that, this manuscript teaches us, that women who have completed their menstruation, puerperal, and istihadah periods required taking purification bath and self purify before worshiping. According to them, the teachings for bathing and self-purifying means teachings to maintain the cleanliness of the women's reproductive organs (vagina), in order to clean themselves from dirty blood. [9].

\section{Methodology}

This type of research is literature study with a philological descriptive approach. The data source of this research is the ancient manuscript. We are trying to compare the contents of the Serat Piwulang Estri text with the Risalah AlMahîd, especially regarding chapters on the types of women's blood. The Serat Piwulang Estri manuscript that we use in this study is Serat Piwulang Estri manuscript which is stored in the Dewantara Kirti Griya museum and not sold freely in stores too-books, while Risalah Al-Mahîd was sold freely in stores too-books.

The stages of data collection began with the collection of Serat Piwulang Estri manuscripts and Risalah Al-Mahîd, followed by studies and direct observations of Serat Piwulang Estri manuscripts and Risalah Al-Mahîd; next is the manuscript description, in this stage the researcher makes a direct reading of the Serat Piwulang Estri manuscript and the Risalah Al-Mahîd, the manuscript reading is done by the literary reception method. 
Descriptive data analysis techniques were used in this study, with stages; manuscript reading, sorting and selection of text contents, presentation of data containing various types of women's blood, and the final process is to compare the data that has been collected both data from Serat Piwulang Estri and from the Risalah Al-Mahîd especially the women's blood chapter.

The data validity tests in this study i.e. the validity and reliability test. The validity test used by researchers here is semantic validity because the data in this study are in the form of words, expressions, sentences, and discourse in accordance with the form of Serat piwulang Estri manuscripts and Risalah Al-Mahîd which is a treatise in the form of prose. The words, expressions, sentences, and discourse in the Serat piwulang Estri and the Risalah Al-Mahîd are not only interpreted textually but also contextual, so that valid meaning is obtained.

To test the validity of the data we used the reliability and interrater reliability tests. In conducting the reliability test, we read the Serat Piwulang Estri manuscript and Risalah Al-Mahîd repeatedly so that the same data were obtained. Perseverance and accuracy in reading the Serat Piwulang Estri script and the Risalah Al-Mahîd are needed to obtain accurate and reliable data. In addition, we also conducted an interrater reliability test that tested and examined the data with consideration and verification of an expert who knew very well about the types of women's blood and their relationship to reproductive health. In this case, the researcher asked for the consideration of an obstetrician in Ponorogo, a doctor. Ratna Widiyastuti, Sp. OG (Jl. MT. Haryono, No. 9 Ponorogo Indonesia).

\section{Findings and Discussion Aspects of Script Philology}

This aspect describes the state of the text Serat Piwulang Estri and Risalah Al-Mahîd both in the physical condition and in content.

\section{Description of Serat Piwulang Estri}

Table 1 - Description of Serat Piwulang Estri

\begin{tabular}{|c|c|}
\hline Sections & Information \\
\hline Title & $\begin{array}{l}\text { The cover title is Piwulang Estri (Javanese letters } \\
\text { in the middle of the inside cover), and the general } \\
\text { title is Serat Piwulang Estri. }\end{array}$ \\
\hline Author & Mas Haji Muhamamad Hajid \\
\hline & Taman Siswa museum, Dewantara Kirti Griya \\
\hline The manuscript repository & $\begin{array}{l}\text { Library, Yogyakarta, Indonesia. } \\
\text { MTS. DKG. } 1.129\end{array}$ \\
\hline The number of collection code & $\begin{array}{l}\text { The color of papers is brownish, without brand. } \\
\text { The cover is carton and the binding was siggy. } \\
\text { Cover and page sheet size } 15 \times 21,7 \mathrm{~cm} \text {. The }\end{array}$ \\
\hline Physical state of the manuscript & $\begin{array}{l}\text { number of lines written on each page } 20 \text { lines. } \\
\text { Distance between lines } 0,7 \mathrm{~cm} \text {. Number of pages } \\
10 \text {. Number of illustrated pages } 1 . \\
\text { Javanese language } \\
\text { Prose }\end{array}$ \\
\hline Language & $\begin{array}{l}\text { Javanese typeface, vertical writing angle, black } \\
\text { ink. }\end{array}$ \\
\hline Form of expression & $\begin{array}{l}\text { Publisher name: N.V. Budi Utama, the } \\
\text { publication year: 1919M, the city: Surakarta, }\end{array}$ \\
\hline Alphabet & $\begin{array}{l}\text { Indonesia. } \\
\text { The text started with bubuka (opening) followed } \\
\text { by the contents of the text which consists of } 6\end{array}$ \\
\hline Publishing & $\begin{array}{l}\text { chapters as follows: khel (menstruation chapter), } \\
\text { holy chapter, puerperal chapter, chapter of } \\
\text { mustahadhoh (istihadah), pangun (maintenance), } \\
\text { and katemton (provisions). }\end{array}$ \\
\hline
\end{tabular}

\section{Description of Risalah Al-Mahîd}

Risalah Al-Mahîd is a book written by Masruhan Ihsan in Brumbung Demak, Central Java, Indonesia around 1956. There is no mention of the year of writing. The following is a description Risalah Al-Mahîd. 
Table 2 - Description of Risalah Al-Mahîd

\begin{tabular}{|c|c|}
\hline Section & Information \\
\hline Title & Risalah Al-Mahîd \\
\hline Author & Masruhan Ihsan \\
\hline The existence of the book & Sold freely in bookstores \\
\hline Physical state of the manuscript & $\begin{array}{l}\text { A kind of book cover like Manila paper, the color } \\
\text { of cover yellow. Cover and page sheet size } 14,5 \mathrm{~cm} \\
x \quad 20,5 \mathrm{~cm} \text {. Number of pages } 47 \text {. Number of } \\
\text { illustrated pages } 1 \text {. The type of paper is opaque. }\end{array}$ \\
\hline Language & Javanese language \\
\hline Form of expression & Prose \\
\hline Alphabet & $\begin{array}{l}\text { Arabic letters (pegon) typeface, vertical writing } \\
\text { angle, black ink. }\end{array}$ \\
\hline Publishing & $\begin{array}{l}\text { No publisher name, no publication year, city } \\
\text { publication: Brumbung, Demak, Indonesia. }\end{array}$ \\
\hline Contents & $\begin{array}{l}\text { Risalah Al-Mahîd contents begin with an opening, } \\
\text { followed by a discussion consisting of } 13 \text { chapters. } \\
\text { Chapter } 1 \text { origin of menstruation, chapter } 2 \\
\text { description of menstruation (information on the } \\
\text { names of menstruation and the animals experiencing } \\
\text { menstruation), chapter } 3 \text { the difference between men } \\
\text { and women, chapter } 4 \text { the beginning of menstruation } \\
\text { (explaining about the age of the woman who's } \\
\text { menstruating for the first time), chapter } 5 \text { explaining } \\
\text { about the time of menstrual bleeding and its } \\
\text { completion, chapter } 6 \text { explaining about various kinds } \\
\text { of menstrual blood, chapter } 7 \text { puerperal, chapter } 8 \\
\text { praying procedures for women in continuous } \\
\text { menstrual conditions, chapter } 9 \text { procedures for caring } \\
\text { for a newborn, chapter } 10 \text {, the ethics of having sex } \\
\text { with a wife), chapter } 11 \text { information about bathing } \\
\text { procedures for women after menstruating, chapter } 12 \\
\text { the ethics and procedures of jinabat bathing, chapter } \\
13 \text {, pregnancy. }\end{array}$ \\
\hline
\end{tabular}

\section{Review's Contents of Serat Piwulang Estri and Risalah Al-Mahîd}

Explained in Serat Piwulang Estri and Risalah Al-Mahîd knowledge about various types of women's blood namely; menstrual blood, puerperal blood, and istihadah. There was also explained that the blood type, among others; strong blood (kuwawi blood / qawi blood) and weak blood (dho'if blood). Menstrual blood color varies i.e. black color, red color, gray color (between red and yellow), yellow color, and murky white, or so-called bloody apes. This manuscript explained also the four types of menstrual blood characteristics i.e. smelling blood, thick blood, thick smelling blood, and watery-odorless blood. [2]

In Serat Piwulang Estri also mentioned that another term for menstruation is khel. Menstruation as described in Serat Piwulang Estri and Risalah Al-Mahîd is blood coming out of a woman's vagina after the age of 9 years, in good health (not due to illness), but it is indeed the nature of women, and not after childbirth. The blood that comes out due to illness is called istihadah (as stipulated in chapter istihadah), and blood that comes out after giving birth is called puerperal.

In terms of their nature some menstrual blood is strong (legally) and some of it is weak. The color of it varies too. The strong blood is red color, blackish-red or gray, and pink, while the weak blood is murky yellow (brownish yellow) or thin. "Dene rupinipun ghetih kuwat punika abrit semu cemeng, utawi kelawu utawi jambon. Menawi ghetih dho'if rupinipun kuning utawi buthek utawi cower." [1].

Thus if there is fluid coming out from the vagina but the color is not one of those five colors, like white fluid that usually comes out after or before menstruation, or when vaginal discharge, then obviously this is not menstrual blood one.

There are four types' characteristics of a woman's blood i.e smelling blood, thick blood, (bacin Javanese), thick smelling blood, and watery-odorless blood. On the perception of fiqih law black-thick blood is stronger than black blood but not thick. Smelly-black blood is stronger than odorless-black blood. The smelly thick blood was stronger than 
thick-odorless blood. So it goes with other types of blood. If two kinds of blood come out together and both of them are stronger blood, like black-thin blood and red-thick blood, the blood that comes out first is stronger than the other. [1]

\section{The Similarities and the Differences Contents of Serat Piwulang Estri and Risalah Al-Mahîd}

There are the similarities and the differences contents of Serat Piwulang Estri and Risalah Al-Mahîd aboud women's blood.

\section{The Similarities Contents}

Both of Serat Piwulang Estri and Risalah Al-Mahîd review the types of women's blood, namely menstrual blood, puerperal blood, and istihadah blood (other than menstrual blood and puerperal blood). Both texts also equally discuss the types of menstrual blood colors i.e. strong blood and weak blood. Strong blood, among others; blackish red, bright red, gray (between red and yellow), pink, and weak blood, among others; yellow and turbid (between yellow and runny white).

Explained in these texts that the time of menstruation at least 24 hours and at most 15 days. If less than 24 hours or more than 15 days it is the blood of istihadah. In this case, the woman is still obliged to pray. Similarly, the puerperal at least than a drop and a maximum of it is 60 days.

Serat Piwulang Estri as well as Risalah Al-Mahîd is both explained that the most powerful blood (legally) is black blood, then bright red, and so on. This does not mean that if a woman has two or more types of blood, strong blood is punished with menstrual blood while others are punished by istikhadoh blood, but during the discharge during menstruation (more than 24 hours and less than 15 days) all are punished with menstrual blood, although what came out was some kind of blood. However, if it exceeds 15 days the strong blood is menstrual blood and the weak blood is istihadah.

For example, a woman on menstruation produces black blood (strong blood) for five days, then she has red blood for twenty-five days, so only the five days is judged menstrual blood, the rest is istihadah because red blood is weaker than black blood. But if the woman bleeds black for five days then she bleeds red for nine days, then all the blood is punished with menstrual blood.

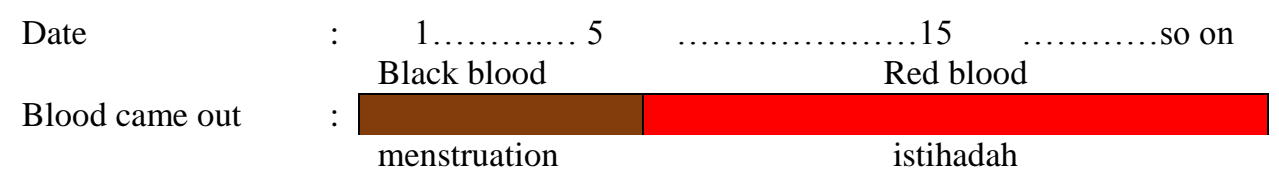

Fig. 1 - Strong blood and weak blood that had been bleeding for more than fifteen days

Indeed, the discussion regarding the blood of istihadah, in the Risalah Al-Mahîd and in the Serat Piwulang Estri is not mentioned in a special chapter but is included in the discussion of menstruation and the puerperium. Among the discussions on istihadah e.g, it was explained there that generally the puerperium is 40 days and a maximum of 60 days, if more than 60 days are still bleeding, then the blood is istihadah blood.

A woman during childbirth first bled the puerperium for thirty days. When she gave birth to the second she bled black for forty days, then she had red blood for fifty days, so she has postpartum blood for forty days, the rest was istihadah.

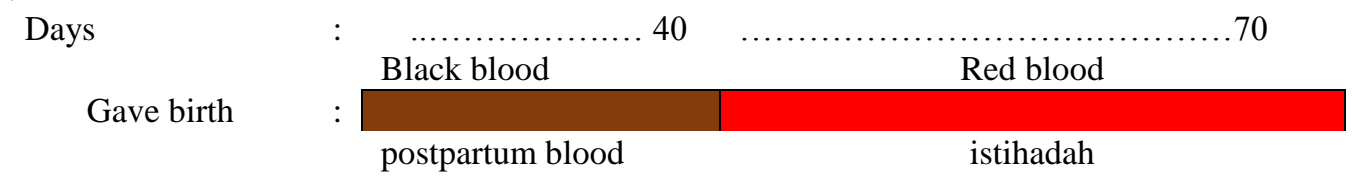

Fig. 2 - Strong blood and weak blood come out more than 60 days

\section{The Differences Contents of Serat Piwulang Estri and Risalah Al-Mahîd}

The different contents of Serat Piwulang Estri and Risalah Al-Mahîd i.e. in the Risalah Al-Mahîd mentioned the pink color blood of menstrual blood. But it is not mentioned in Serat Piwulang Estri. It was also told in Risalah AlMahîd the history of the origin of women bleeding menstruation was when Eve (Adam's wife) violated Allah's prohibition to cut the khuldi tree in heaven, but Eve cut part of the tree because of Devil seduction. The tree sap fell to Eve's body, and then God punished Eve by bleeding through her vagina. It then became her habit every month, even when Eve had been sent down to earth, each month she was still bleeding menstrual. In the Serat Piwulang Estri those story is not told. 
In the Risalah Al-Mahîd also explained, in addition to humans there are also some animals that experience menstruation every month such as bats, rabbits, monkeys, and others. The chapters about women which is explained in the Risalah Al-Mahîd but not explained in the Serat Piwulang Estri or explained there but only briefly i.e. the prayers of people who are constantly in a major state condition, procedures for caring for babies, manners to treat a wife, and problems pregnancy. These problems are not explained in Serat Piwulang Estri.

\section{Health Elements in Serat Piwulang Estri and Risalah Al-Mahîd}

The health elements with is can be analyzed both from the Serat Piwulang Estri and the Risalah Al-Mahîd are an explanation of the start and stop times of menstruation, as well as its time of the puerperal. As quoted in Serat Piwulang Estri especially the first part of the menstrual chapter noted that "besides that, if a women bleeding menstruation not enough than a day and a night or less than 24 hours the blood is called istihadah and so do if the menstruation more than fifteen days,". Istihadah blood is neither menstrual nor puerperal blood. We can be doing analyzed toward this statement that it is at the same time is a warning for women to be more vigilant when in istihadah condition in order to maintain the health of their reproductive organs.

Concerning the time of menstruation, explained also in Risalah Al-Mahîd that if the time of menstruation for 5 or 7 days but not smooth enough or less than a day and a night or less than 24 hours, this blood is judged as blood istihadah. Thus, it is recommended to see a doctor. So do if the time of menstruation is more than 15 days, then the rest will also be judged as istihadah and recommended seeing a doctor.

At the beginning of the menstrual chapter, it was explained that a healthy woman every month must be having menstruation if not, the woman is not healthy. Menstrual blood is dirty blood, to be a healthy woman her dirty menstrual blood must come out. Like a boil, so that boils can heal, dirty blood from inside it must be removed.

In Serat Piwulang Estri as well as in Risalah Al-Mahîd is explained that after menstruation is finished, and after the postpartum women are required to take a purification bath. This is because menstrual blood is dirty blood that must be cleaned when going to start worship. Purification baths also have certain rules to achieve holiness or cleanness. This can also have an impact on the cleanliness of the female reproductive organs and the cleanliness of the whole body.

In Risalahal-Mahid also explained that women who experience menstruation are prohibited from having sex. This is in accordance with Hasanah's research that Islam places strict limits on sexual activity that will be carried out during menstruation because there are negative effects, one of which is a disability in children. It also has an impact on the health of the reproductive organs both male and female.

Both Serat Piwulang Estri and Risalahal-Mahid not explain the causes of various menstrual blood colors. But according to medical experts, the different blood colors are usually caused by the discharge of menstrual blood timely or not. For example, brownish-red is usually the remaining blood of the previous month. The blackish-red blood color is caused due to the time of retreating menstruation; the blood in the reproductive organs does not immediately come out so that it becomes blackish red. The cause of the decline in menstrual time can be caused by stress (mind) or tired. But menstrual blood color that is too black and thick can also be caused by diseases that exist in the female reproductive organs. Women who experience this condition need to consult a doctor immediately. (Interview with Doctor Ratna Widiyastuti, September 19, 2019).

The bright red color of menstrual blood indicates a healthy condition, normally this condition occurs on the second and third days of menstruation, this is caused by the uterine lining releases an unfertilized egg, and the uterine lining decays very quickly, or so fast that there is no time for other molecules to darken the color of the blood. Menstrual blood color is pink, according to Doctor Ratna Widiyastuti due to lack of estrogen levels. Usually, this condition accompanied by a very small volume of menstrual blood and irregular menstruation. Lack of estrogen can cause vaginal dryness, body weakness, and decreased sexual desire. If the menstrual blood color is gray, it is recommended that the woman in question consult a doctor because this could be a symptom of an infection or miscarriage. The woman may not be aware that she is pregnant. (Interview with Doctor Ratna Widiyastuti, September 19, 2019).

After knowing the cause of each blood color, it is hoped that women will be more vigilant if they experience menstruation and secrete pink color blood, or secrete gray color blood because of the possibility of infection in their reproductive organs. It is better to consult a doctor immediately.

\section{Conclusion}

It is can be concluded from this explanation that the types of women's blood mentioned in the Risalahal-Mahid as well as in Risalahal-Mahid are menstrual blood, puerperal blood, and istihadah blood. Blood that comes out fom a healthy woman's vagina every month on more than 24 hours and less than 15 days is menstrual blood. Besides, it is istihadah blood. Blood that comes out after a woman after gives birth for no more than 60 days is puerperal blood, more than that is istihadah blood. Various kinds of menstrual blood, namely strong blood, among others: blackish red, bright red, gray (between red and yellow), and pink. While the weak blood i.e yellow and cloudy (between yellow and white).

The Medical side of Serat Piwulang Estri and Risalah Al-Mahîd i.e. first, this text teaching about the obligation for women after menstruation and after puerperal must take a purification bath, because the blood that comes out of a woman's vagina is dirty. The lessons can be taken from the obligation to take a bath is to protect the female 
reproductive organ cleanliness. Second, menstrual blood which is black blood (blackish-red) indicates healthy reproductive organs, bright red menstrual blood indicates healthy reproductive organs, pink blood color indicates less healthy reproductive organs because estrogen hormone is decreased, so the body feels weak, and menstrual blood color gray indicates unhealthy reproductive organs because of the possibility of infection in the uterus, or maybe the woman is unwittingly pregnant and she is having a miscarriage.

\section{Acknowledgement}

Thank you for the main contribution of the Librarian at the Dewantara Kirti Girya, Taman Siswa Museum, Yogyakarta, Indonesia, for helping to provide data on Serat Piwulang Estri manuscripts, Thank you for the support from Institut Agama Islam Riyadlatul Mujahidin (IAIRM) Ngabar Ponorogo, Indonesia. Thank you for the main contribution of Dr. Ratna Widiyastuti Ponorogo, Indonesia.

\section{References}

[1] Masruhan Ihsan, Risalah Al-Mahid. Brumbung Demak: t.p

[2] M. H. M. Hajid, Serat Piwulang Estri. Surakarta: N.V Budi Utama, 1919

[3] BKKBN, Masalah Kesehatan Reproduksi Dan Alat Obat Metode Kontrasepsi. Surabaya, 2014

[4] BKKBN, Kesehatan Reproduksi Remaja. Surabaya, 2005

[5] H. Hasanah, "Pemahaman Kesehatan Reproduksi Bagi Perempuan," Sawwa, vol. 11, no. 2, pp. 229-252, 2016

[6] Damono, Sosiologi Sastra: Sebuah Pengantar Ringkas. Jakarta: Pustaka Jaya, 1978

[7] U. Masfiah, "Respon Santri Terhadap Kitab Risalah Al-Mahid Sebagai Pedoman Haid Santri di Pesantren Manbail Futuh, Jenu, Tuban, Jawa Timur,” vol. XVII, no. 02, pp. 243-262, 2010

[8] A. Wulandari, "Piwulang Estri sebagai Bentuk Reportase tentang Wanita Jawa (Profil Kepemimpinan RajaRaja Wajo Sulawesi Selatan dalam Lontaraq Akkarungeng Ri Wajo)," Manuskripta, vol. 6, no. 2, pp. 1-17, 2016

[9] F. Y. Ismawarsari, U. Hasanah, and D. K. Ningrum, "Kesehatan Wanita Berdasarkan Studi Teks Serat Piwulang Estri Dalam Kajian Filologi Sebagai Khasanah Kebudayaan Jawa,” Pelita, vol. XI, pp. 14-20, 2016 